\title{
Effect of aqueous and alcoholic extracts of Ziziphora clinopodioides on apoptosis and alteration of caspase- 3 and caspase- 9 gene expression in anterior horn neurons of the spinal cord after sciatic nerve compression in male rats
}

\author{
Iman Abdolamir Abdolsamad Halaf ${ }^{1}{ }^{1}$, Maryam Tehranipour ${ }^{1 *}$, Homa Mahmodzadeh \\ Akharat 1
}

\begin{abstract}
Background and Aim: Caspase family genes promote degeneration and are involved in apoptotic processes. The Ziziphora clinopodioides from the mint family (Lamiaceae) is one of the plants strong with antiinflammatory effects and involved in the process of nervous system repair. The present study aimed to determine the effects of aqueous and alcoholic extracts of Ziziphora clinopodioides on apoptosis and alteration of caspase- 3 and caspase- 9 gene expression after sciatic nerve compression in male rats.
\end{abstract}

Materials and Methods: In the present study, 24 male Wistar rats weighing 200-250 g were randomly assigned to four groups ( $\mathrm{n}=6$ in each group): control, compression, treatment with aqueous, and treatment with alcoholic extracts at a dose of $75 \mathrm{mg} / \mathrm{kg}$. The extract was injected intraperitoneally on compression day and seven days later. After 28 days, samples were taken from the lumbar spinal cord subsequent to performing the perfusion method, and the samples were studied in two ways. Thereafter, in each group, total RNA was extracted from the lumbar spinal cord, cDNA was synthesized; subsequently, the expression changes in caspases- 3 and caspases- 9 were compared.

Results: Based on the results, the number of neurons significantly decreased in the compression group, as compared to that in the control group, and demonstrated a significant increase in the aqueous extract group, in comparison with the compression group. Furthermore, the amount of caspases-3 and caspases-9 expression increased significantly in the compression group, compared to that in the control group. Moreover, caspase- 3 and caspase-9 gene expression increased in the aqueous extract group, as compared to that in the compression group $(\mathrm{P}<0.001)$.

Conclusion: It seems that, the extract of Ziziphora clinopodioides has neuroprotective effects due to its antioxidant and anti-inflammatory properties, as well as phenolic and flavonoid compounds, such as pulegone.

Keywords: Apoptosis, Degeneration, Neuron, Ziziphora clinopodioides

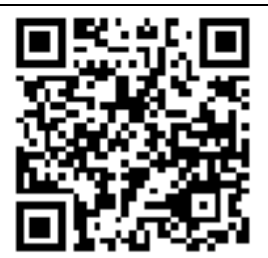

Citation: Abdolsamad Halaf IA, Tehranipour M, Mahmodzadeh Akharat H. [Effect of aqueous and alcoholic extracts of Ziziphora clinopodioides on apoptosis and alteration of caspase- 3 and caspase- 9 gene expression in anterior horn neurons of the spinal cord after sciatic nerve compression in male rats]. J Birjand Univ Med Sci. 2021; 28(3): 222-235. [Persian]

DOI http://doi.org/10.32592/JBirjandUnivMedSci.2021.28.3.101

Received: March 8, $2021 \quad$ Accepted: August 9, 2021

${ }^{1}$ Department of Biology, Islamic Azad University, Mashhad Branch, Mashhad, Iran

*Corresponding author: Department of Biology, Islamic Azad University, Mashhad Branch, Mashhad, Iran

Tel: +989155110370

E-mail: maryam_tehranipour@mshdiau.ac.ir 


\title{
بررسى اثر عصار هماى آبى و الكلى كياه كاكوتى (Ziziphora clinopodioides) بر روند آيوپتوز و

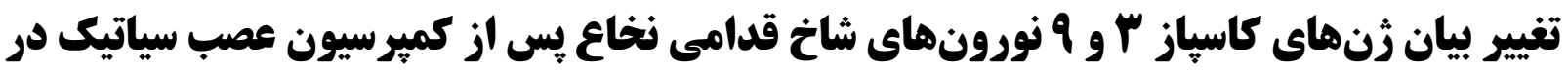 رتهاى نر
}

\author{
'ايمان عبد الامير عبد الصمد حلاف (iD)'، مريم طهرانى يور (D) '** هما محمودزاده آخرت (iD) '
}

\begin{abstract}
جكکبه

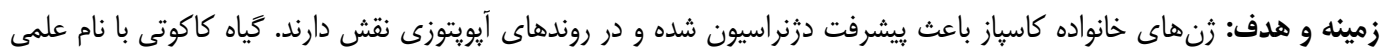
Ziziphora clinopodioides

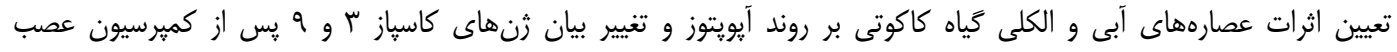
سياتيك در رتهاى نر انجام شد.

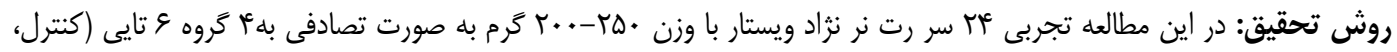

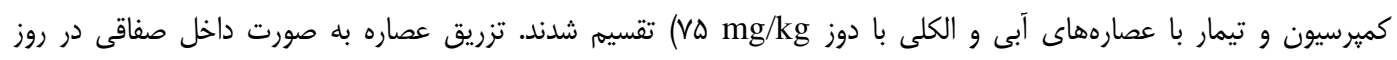

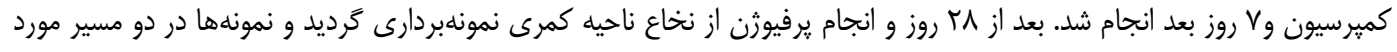

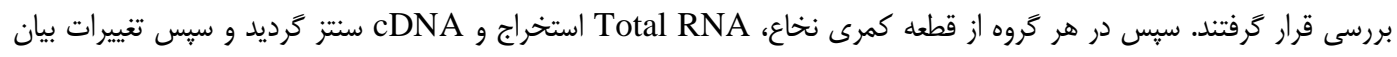
ثن هاى كاسياز س و 9 مقايسه شد.

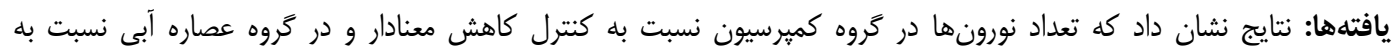

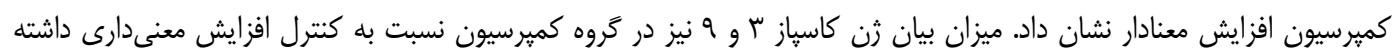

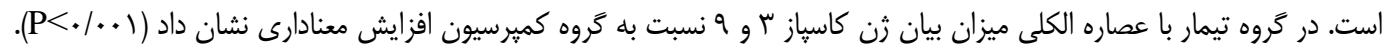

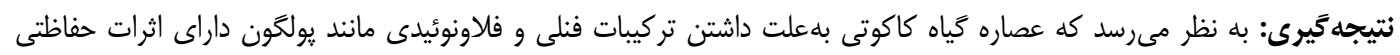

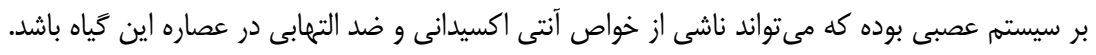
وازههاى كليدى: آيويتوز، دزنراسيون، نورون، كاكوتى

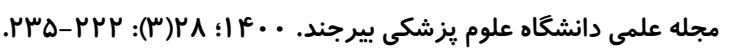

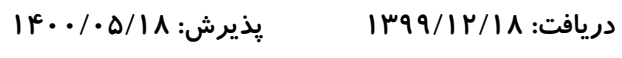


عملكرد ساير دستخاههاى بدن مورد توجه اكثر محققان مىباشد. يكى از خياهانى كه در روند ترميم سيستم عصبى نقش دائمانه دارد، كياه

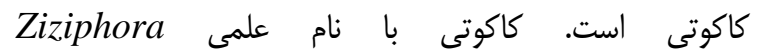
linopodioides

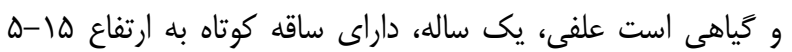
سانتىمتر و بركَهاى نوى تيز و باريك كه در اغلب نواحى ايران

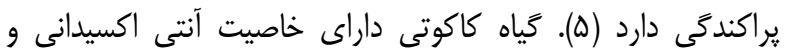

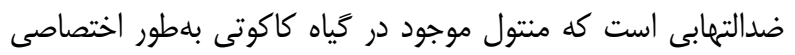
توليد بّ مدياتور اصلى التهاب توسط مونوسيتها را مهار مى كند (؟).

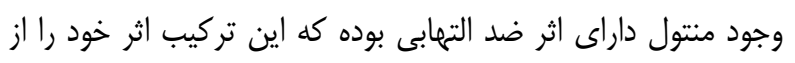

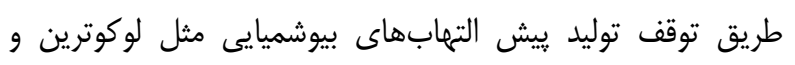

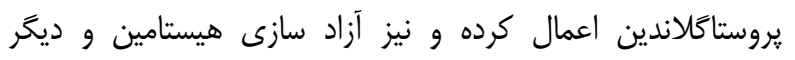

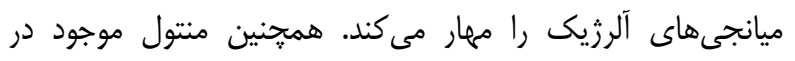

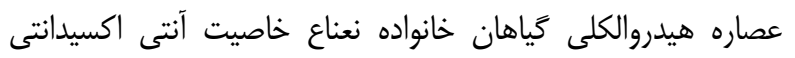

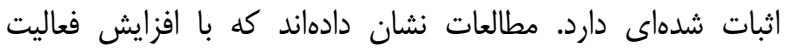

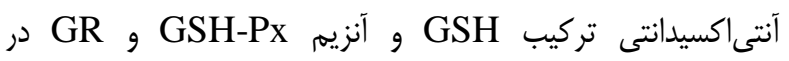
گروههاى حاوى منتول باعث كاهش ميزان سيتوكينهاى التهابى مانند فاكتورهاى نكروز كننده تومورى آلفا (TNF-

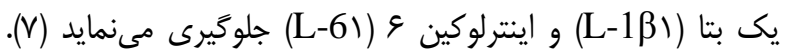
كاكوتى حاوى غلظت بالايى از آنتى اكسيدانتها مىباشد كه اين

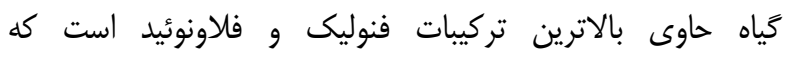

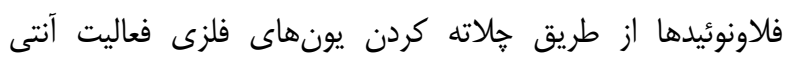

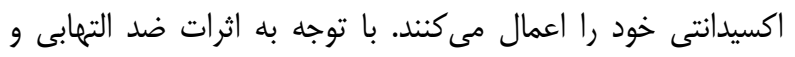

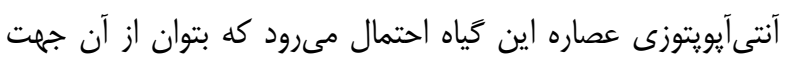

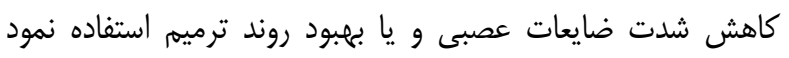

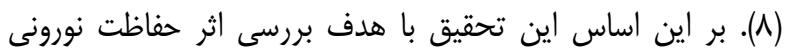

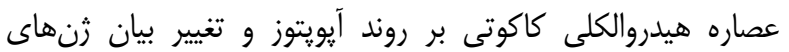

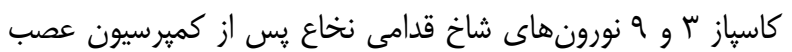
سياتيك در موشهاى صحرايى نر انجام شده است. مقلdمه

كاسيازها جزء خانواده سيستئين يروتئاز هستند كه نقش محورى

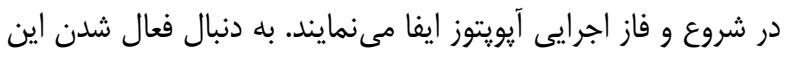

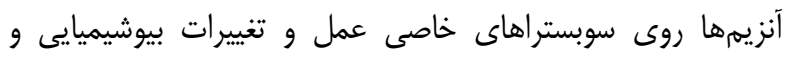
مورفولوزيك در سلول آيويتوتيك ايجاد مىنمايند. خانواده كاسيازها

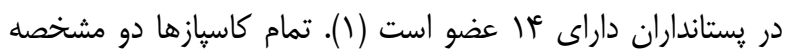

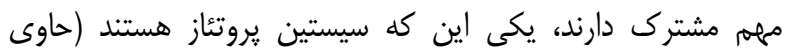

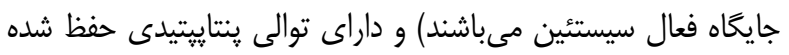
OACXG

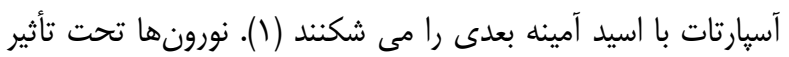

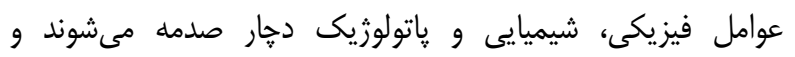
تخريب (دزنراسيون) آنها يك صدمه دائمى محسوب مى شود (T). هنكًامى كه يك عصب قطع مى شود، ارتباط آكسون با جسم سلولى مُنى

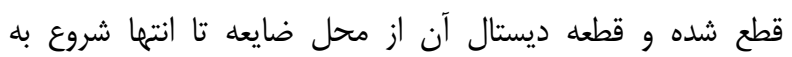

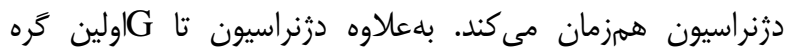

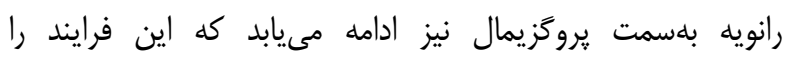

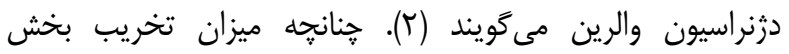

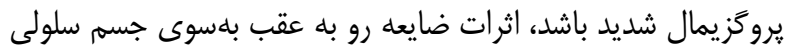
توسعه يافته و سبب دزنراسيون مركزى (تخريب جسم سلولى) مىشود، اجسام نيسل شكسته شده و در سرتاسر سيتويلاسم يراكنده

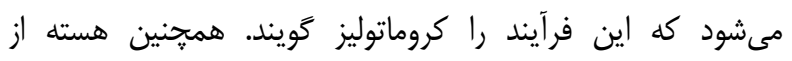

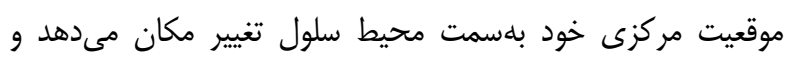

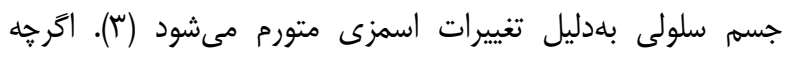
نورونها عموماً يس از تولّد فاقد قدرت تكثير مىباشند؛ امّا مى توانند

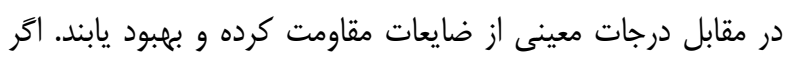

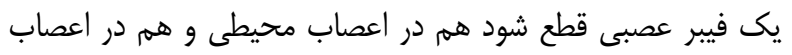

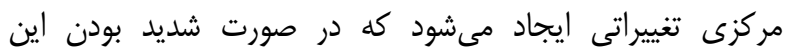

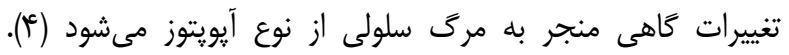

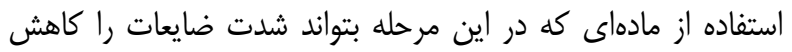

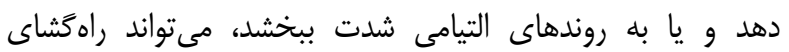

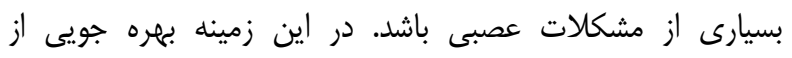

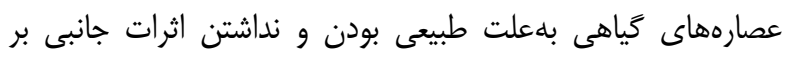


روزهاى اول همزمان با كميرسيون و در روز هفته بلهورت درون صفاقى تزريق شد. رتهاى هر گروه با تزريق داخل صفاقى ماده

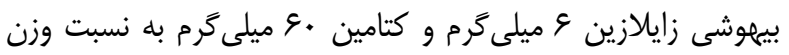

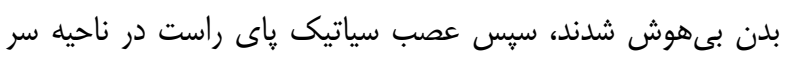

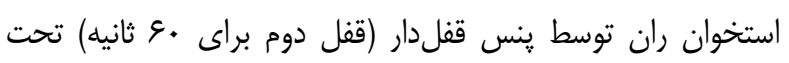

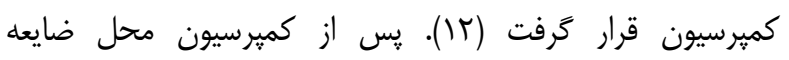
ضدعفونى و توسط كيره فلزى بخيه زده شد. بعد از اين كه موشها

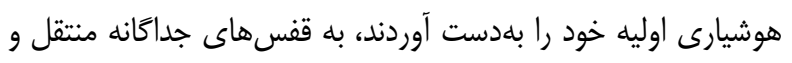

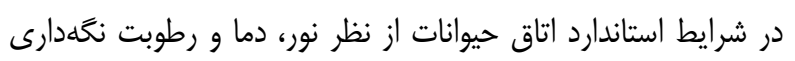
شدند. در كروههاى تيمار اولين تزريق عصاره بلافاصله بعد از انجام

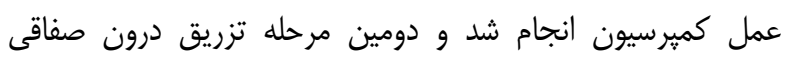

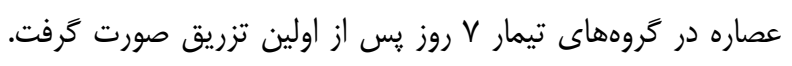

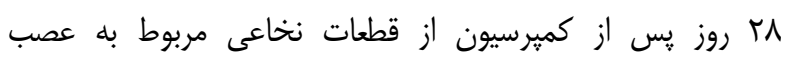

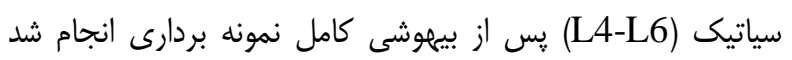

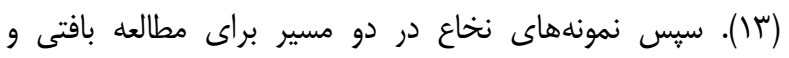

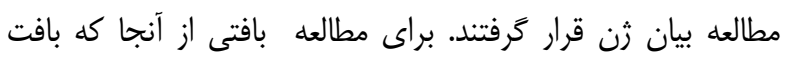
عصبى بافتى حساس است و به سرعت دهار فرآيندهاى اتوليز

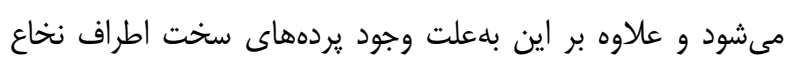

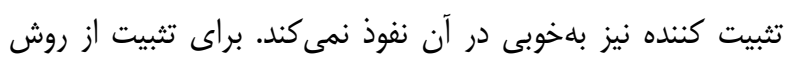

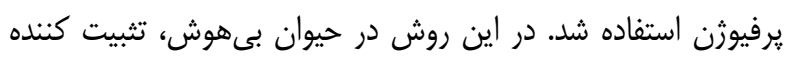
(فرمالين •ا درصد نمكى) در بسترهاى عروقى جريان مىيابد (باس).

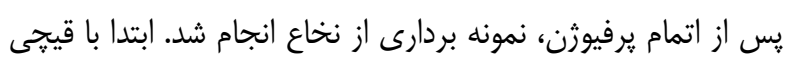
ناحيه قفسه سينه باز شده تمام محتويات قفسه سينه و شكم خارج مىشود سبِ در ناحيه مهرههاى قفسه سينه با اسكاريل ستون

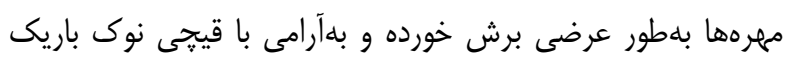

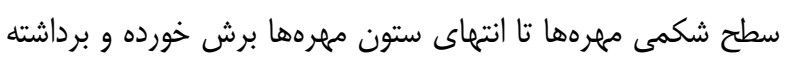

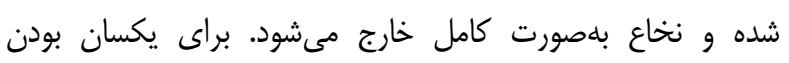

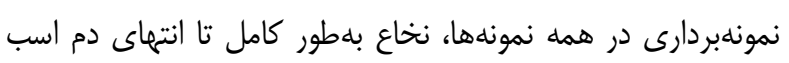

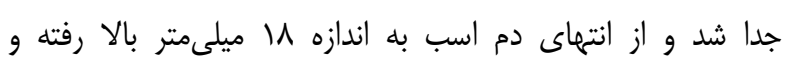

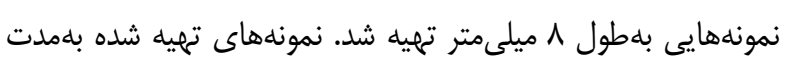

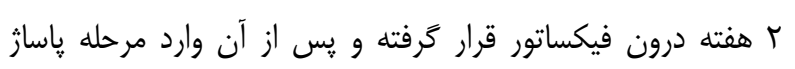

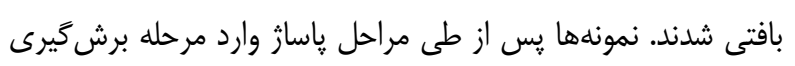

\section{روش تحقيق}

در اين مطالعه بلهنظور رعايت اصول اخلاقى، كار بر روى دوى حيوانات بر اساس يروتوكل هلسينكى و دستور كار انجمن علوم

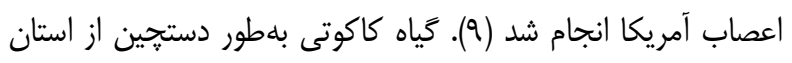
خراسان رضوى و توابع شهرستان مشهد جمعآورى شد. اين كياه

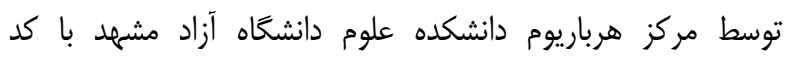

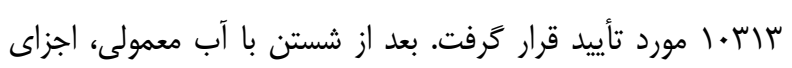

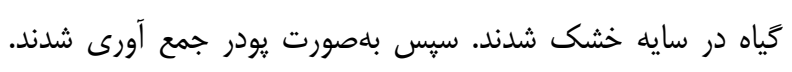

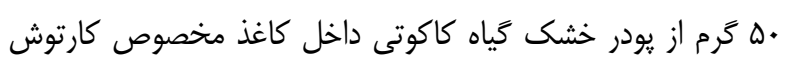

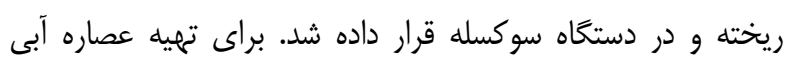

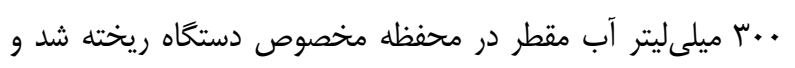

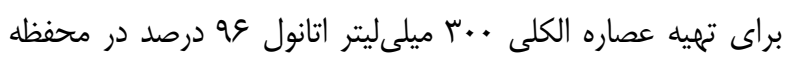
مخصوص دستخاه ريخته شد. همجنان كه كيسه حرارتى دستخاه،

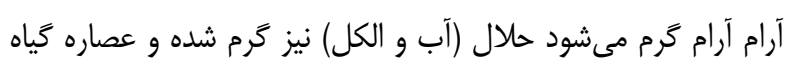

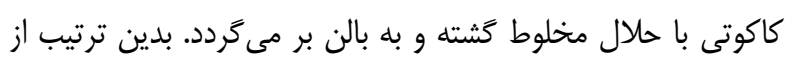

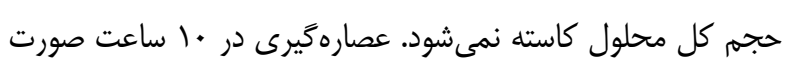

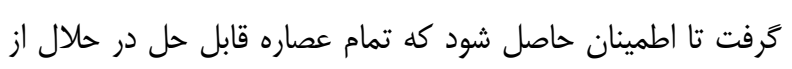
يودر استخراج شده است. براى حذف حلال عصاره بلهدست آمده در حرد

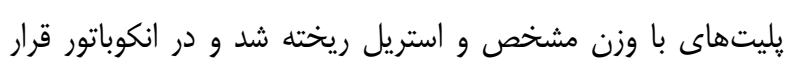
داده شد تا كاملاً حلال حذف گرديد (· (1). موشهاى صحرايى نر از

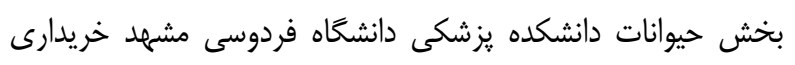

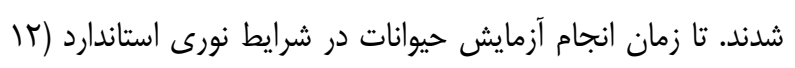

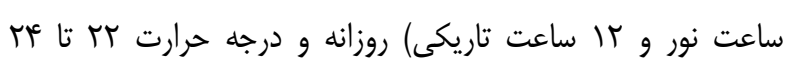

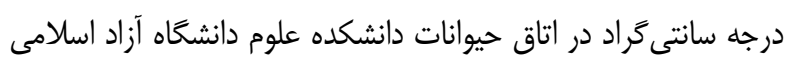

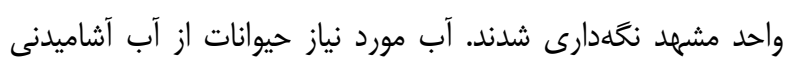
شهر و غذاى آنها نيز داراى فرمول استاندارد و از شركت جوان نوانه خراسان تهيه شد. در اين تحقيق ع س سر موش صحرايى نر نزاد

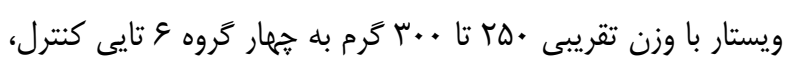

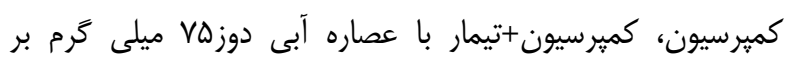

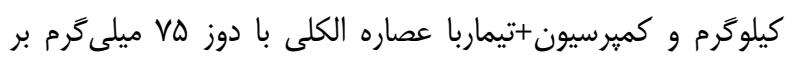
كيلوَّرم تقسيم شدند. بهصورت تجربى در مطالعات قبلى اثبات شده

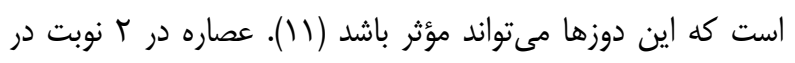




\section{روش انجام آزمايش جهت بر رسى بيان ثن

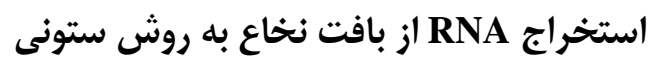 \\ مواد مورد نياز:}

كيت استخراج RNAColumn RNA isolation Kit III

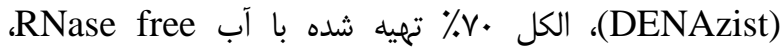

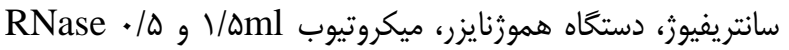

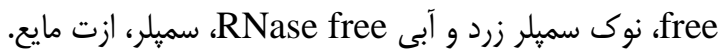

\section{روش كار}

ابتدا از بافت نخاع نمونه بردارى شد. سيس مراحل استخراج

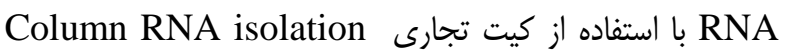
Kit III (DENAzist)

\section{الف: مرحله آماده سازى}

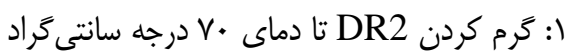

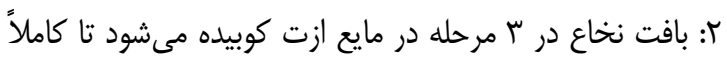

$$
\text { يودر شود. }
$$

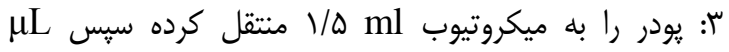
DR1 VVD به آن اضافه مى شود.

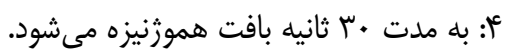

ه: إ ه دقيقه در محيط مىماند.

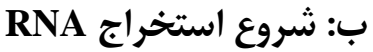

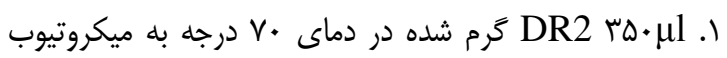

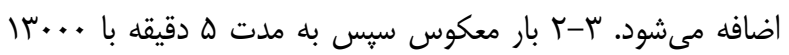

دور سانتريفيوز مىشود.

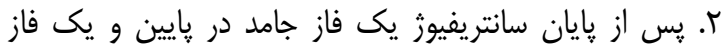

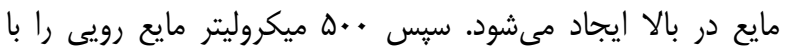

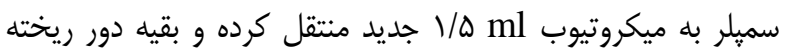

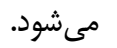

r.

$$
\text { معكوس مى شود. }
$$

أ. مايع حاصل بلافاصله به ستونهاى استخراج منتقل مى شود.

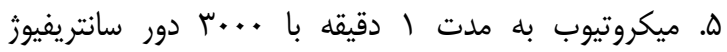

شده، برشگيرى با استفاده از دستخاه ميكروتوم انجام شد.

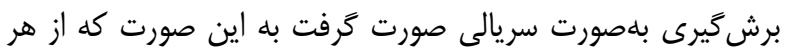

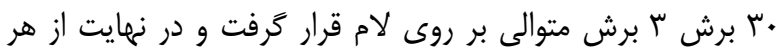

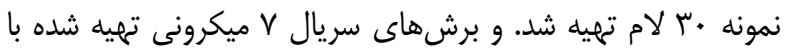

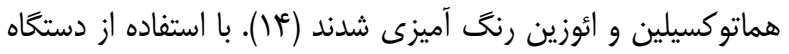
فتوميكروسكوٍ از منطقه شاخ قدامى نخاع در سمت راست در

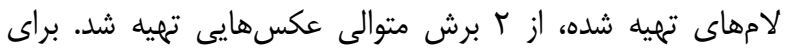
شمارش نورونهاى حركتى آلفا شاخ قدامى نخاع در سمت راست، از لز

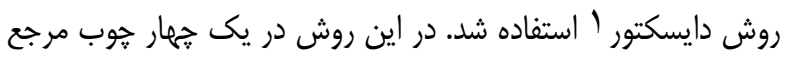

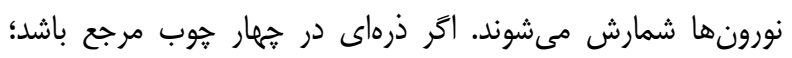
ولى در جهار حوب بعدى (در برش متوالى بعدى) نباشد، در شمارش

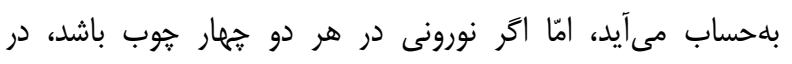

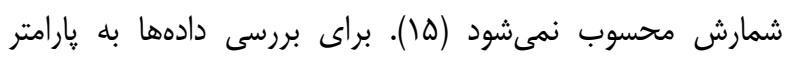

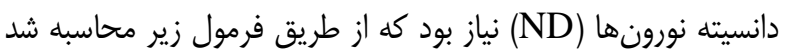

$\mathrm{ND}=\mathrm{a} \mathrm{Q} / \mathrm{a} F r a m e \times \mathrm{V}$ dissector مجموع نورونهاى شمارش شده در يك نمونه : Fframe V dissector Vdissector $=\mathrm{A}$ Frame $\times \mathrm{H}$ مساحت جهار خوب نمونه بردارى A Frame: H

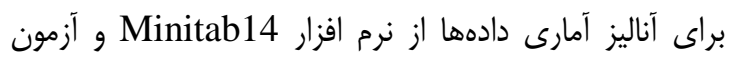
Anova نمودارها از نرم افزار Excell استفاده كرديد. براى بررسى بيان ثن در نمونههايى كه بدون يرفيوزن انجام

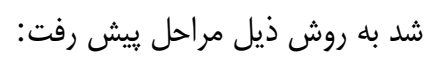

${ }^{1}$ Disector 
Random hexamer 200ng/ $\mu$ -

DEPC-treated wather RT-preMix $(2 x)-$

\section{PCR دمتَاه مورد نياز: دستخاه}

روش كار:

براى انجام واكنش RT-PCR از روى RNA، با استفاده از آنزيم CDNA مي مسازيم. براى Reverse Transcriptase

$$
\text { سه جفت برايمر وجود دارد. }
$$

اليخو دى تى 16 Oligo (dT) يرايمرى است كه وجا باز دارد

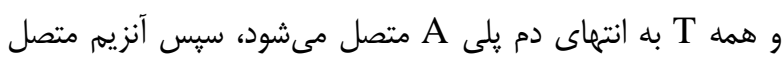

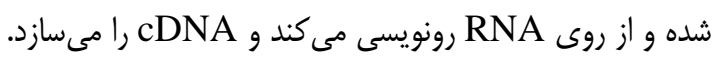

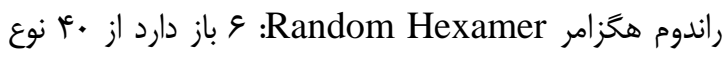
باز به صورت رندوم توالى هاى 9 تايى مى سازد؛ هون طول آن كوتاه

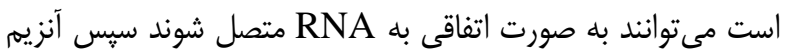
به انتهاى برايمر متصل مىشود و رونويسى مى كند. mRNA يرايمر اختصاصى است. Speciphic primer مربوط به زن خاصى است. يرايمر اختصاصى طراحى مى كنيه. به

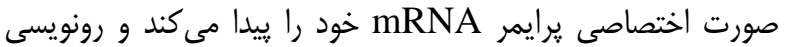

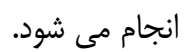

\section{cDNA مراحل ساخت}

بسته به غلظت RNA در هر نمونه بين r تا ه/ ب ميكروليتر از نمونه RNA نرمال و تيمار برداشته شد. Oligo (dT) به هر نمونه اضافه كرديد. به هر ميكروتيوب آنقدر Wather DEPC اضافه گرديد كه حجم به 14 - ال برسد.

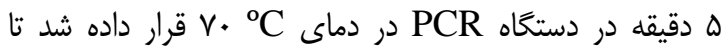
ساختارهاى ثانويه از بين برود. نمونه ها جند دقيقه روى يخ قرار كرفت. به هر ميكروتيوب RT premix(2x)| • اضافه شد سبس توسط سمبلر كاملا ميكس كرديد. نمونه ها •ا دقيقه در دماى

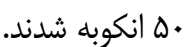

مى گردد و پِس از هر سانتريفيوز مايع جمع شده در لوله جمع كننده پايين ستون دور ريخته مى شود.

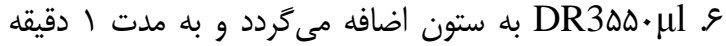

$$
\text { با .... با دور سانتريفيوز مىشود. }
$$

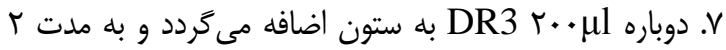

$$
\text { دقيقه با ....rا دور سانتريفيوز مىشود. }
$$

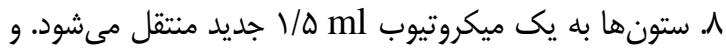

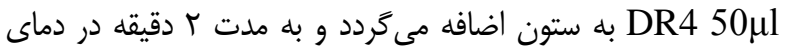
اتاق مى ماند، سبس ז دقيقه با ...1 دور سانتريفيوز مىشود.

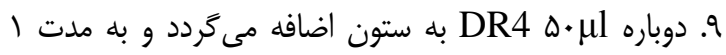
دقيقه در دماى اتاق مى ماند سيس ץ دقيقه با .... با دور سانتريفيوز مى شود. •.. ستونها دور انداخته مىشود و بl. +1 محلول حاصل

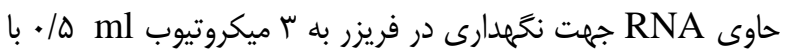
نسبت •r : • أ : • أ منتقل مىشود. Total RNA . . Tى حاصل توسط دستگاه نانودراب تعيين

$$
\text { كيفيت و كميت مىشود. }
$$

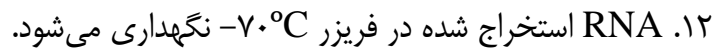

\section{كنتر ل كيفيت RNA استخراج شده}

با استفاده از تكنيك اسيكتروفتومترى و دستخاه نانودراب از

كيفيت RNA و استخراج صحيح آن اطمينان حاصل شد. اين

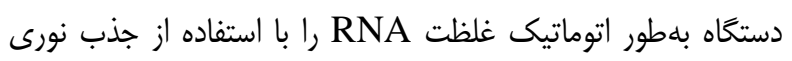
در طول موج • ع نانومتر، محاسبه مى كند. يّ از آمادهسازى نمونه

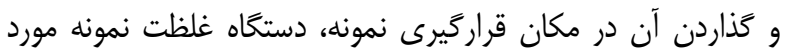

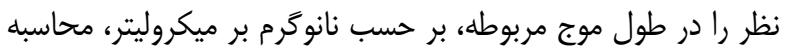
مىنمايد (1) (1).

سنتز cDNA

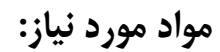
Total RNA Oligo (dT) 16 500ng/ $\mu \mathrm{l}$ - 
شده با رنخهاى فلورسانس در انتهاى'ه يا 'ب استفاده مىشود، كه

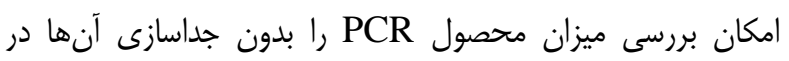

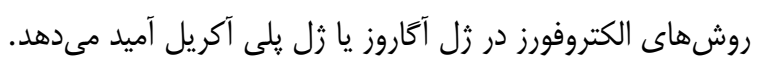

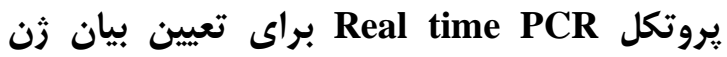

$$
\text { كاسياز س و } 9
$$

يروتكل بيشنهادى مطابق جدول ا مىباشد.
براى توقف واكنش نمونه ها به مدت • ا دقيقه در دماى

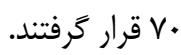

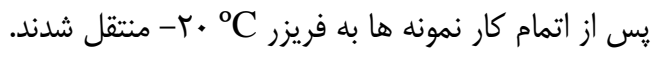

جدول ا - توالى يرايمر مورد استفاده براى بررسى بيان زن كاسباز س و GAPDH

\begin{tabular}{|c|c|c|}
\hline زن & توالى يرايمر & دما \\
\hline \multirow{2}{*}{ كاسياز } & GCTGACTTCCTGTATGCTTAC & 57.87 \\
\hline & GGAAGGTGGCAACGGAAT & 55.97 \\
\hline GAPDH & ATTGCTGACAGGATGCAGAA & 55.25 \\
\hline
\end{tabular}

جدول r- توالى برايمر مورد استفاده براى بررسى بيان ثن كاسباز 9 و GAPDH

\begin{tabular}{|c|c|c|}
\hline زن & توالى يرايمر & دما \\
\hline \multirow{2}{*}{ كاسياز9 } & TCTCTTCATCTCCTGCTTAG & 53.69 \\
\hline & GCAAAGGAGCAGAGAGTA & 55.25 \\
\hline GAPDH & TAGAGCCACCAATCCACAC & 56.67 \\
\hline
\end{tabular}

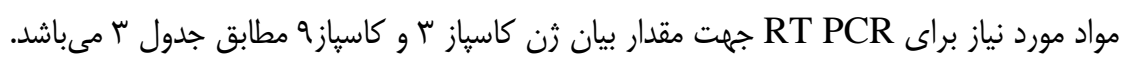

جدول ب- مواد مورد نياز RT PCR

\begin{tabular}{|c|c|c|}
\hline تركيبات & حجم & نهايى \\
\hline $\begin{array}{c}\text { SYBR Green PCR } \\
\text { Master mix }(2 \mathrm{x})\end{array}$ & $10 \mathrm{ul}$ & $1 \mathrm{x}$ \\
\hline Forward primer & $2 \mathrm{ul}$ & 100um \\
\hline Reverse primer & $2 \mathrm{ul}$ & 100um \\
\hline Template Cdna & $2 \mathrm{ul}$ & $0.5-1 \mathrm{um}$ \\
\hline Sterilized D.W & $4 \mathrm{ul}$ & - \\
\hline Total volume & 20ul & - \\
\hline
\end{tabular}

برنامه دمايى Real Time PCR براى بيان زن كاسياز سّ كاسياز 9

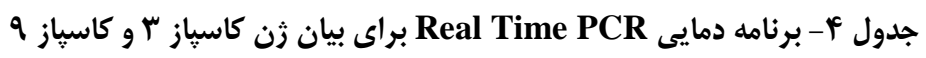

\begin{tabular}{|c|c|c|}
\hline دما & زمان & سيكل \\
\hline 95 & $1 \mathrm{~min}$ & 1 \\
\hline 95 & $15 \mathrm{sec}$ & \\
\hline 59 & $30 \mathrm{sec}$ & 40 \\
\hline 72 & $30 \mathrm{sec}$ & \\
\hline 95 & $10 \mathrm{~min}$ & 1 \\
\hline
\end{tabular}




\section{يافته ها}

شمارش نورونهاى حركتى آلفا و دانسيته نورونى در شاخ قدامى نخاع در كروههاى مختلف نشان داد كه يديده كمبرسيون

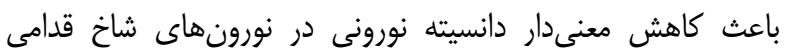

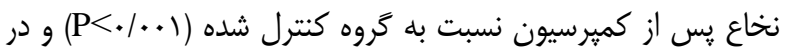

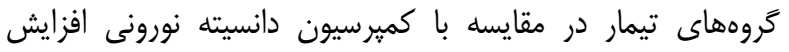

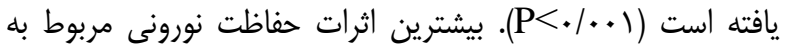
عصاره آبى بود.

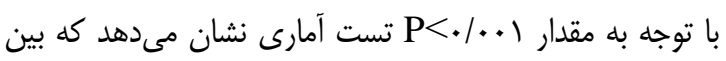
گروه كميرسيون و گروه تيمار عصاره آبى (كميرسيون+تيمار با دوز

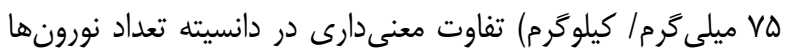

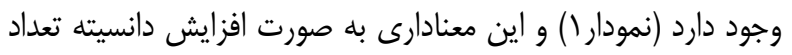

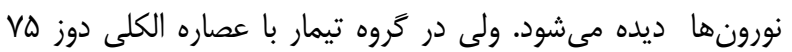
دانسيته نورونى نسبت به كميرسيون افزايش معنىدارى ندارد .$(\mathrm{P}=\bullet / .9)$

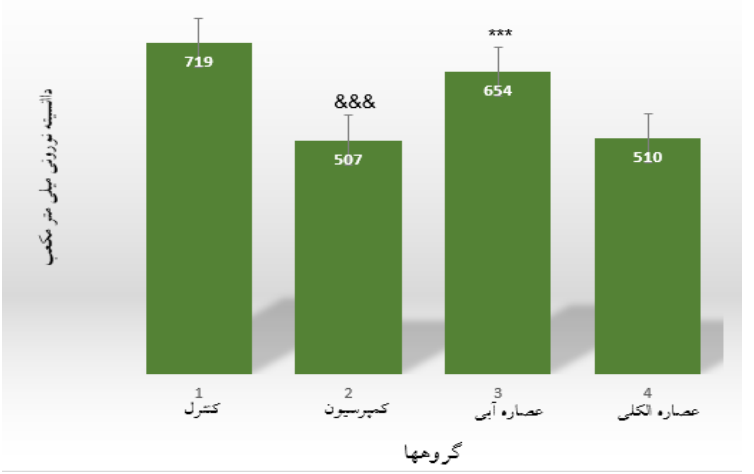

نمودار ا - مقايسه دانسيته تعداد نورونهاى حركتى آلفا در شاخ

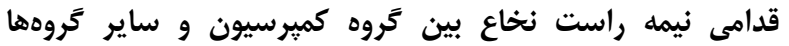

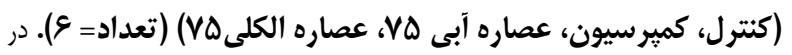

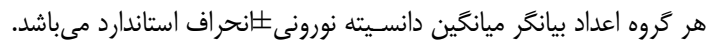

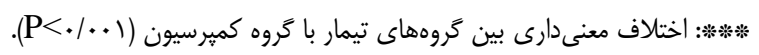

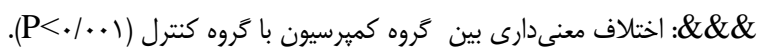

\section{Real time PCR مراحل}

به طور كلى Real time PCR جند مرحله دارد (تصوير ): فاز اول The baseline region: با وجود اينكه محصول دو رشتهاى وجود دارد ولى نور آن قابل رديابى نيست. فاز دوم The exponential phase: محصول دو رشتهاى در هر خرخه دو برابر مىشود و رشد نمايى مربوط به واكنش شروع

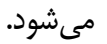
فاز سوم The liner phase: تركيبات واكنش و كارايى آنها روبه اتمام است. فاز جهارم The plateau phase: تركيبات واكنش از بين مىروند و افزايش در ميزان فلورسنت مشاهده نمىشود (IV).

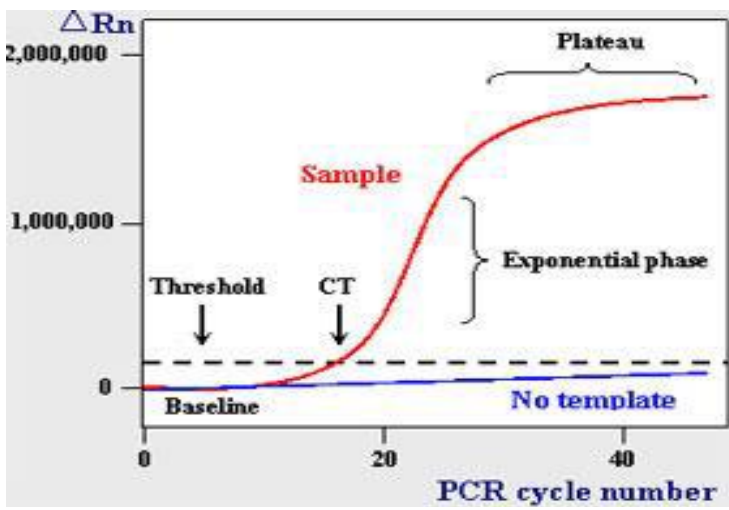

Real time PCR تصوير 1- مراحل

آناليز آمارى دادهها

براى آناليز آمارى دادهها از نرم افزار MxPro و آزآماري

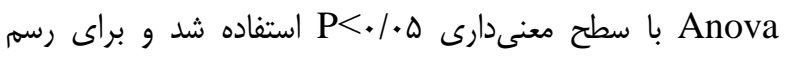
نمودارها از نرم افزار Excell استفاده كرديد.

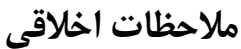

ياياننامه با عنوان بررسى اثر عصارههاى آبى و الكلى كَياه كاكوتى بر روند آيويتوز و تغيير بيان زنهاى كاسياز ب و و 9 در نورونهاى شاخ قدامى نخاع پِ از كمبرسيون عصب سياتيك در

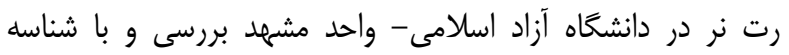

$$
\text { اخلاق IR.IAU.MSHD.REC.1399.108 مصوب كرديد. }
$$




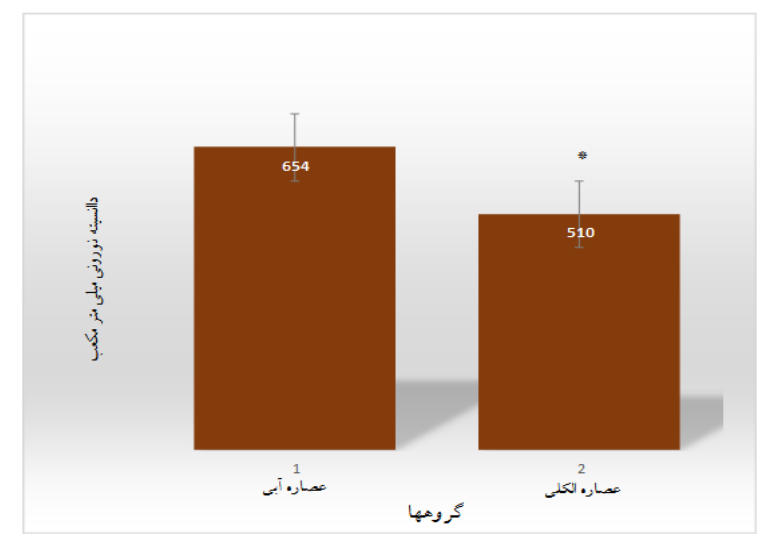

نمودار ب- مقايسه دانسيته تعداد نورونهاى حركتى آلفا شاخ قدامى

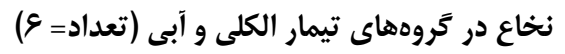

در هر كروه اعداد نشان دهنده ميانكين ثلانحراف معيار مى باشد.

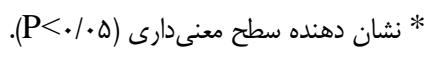
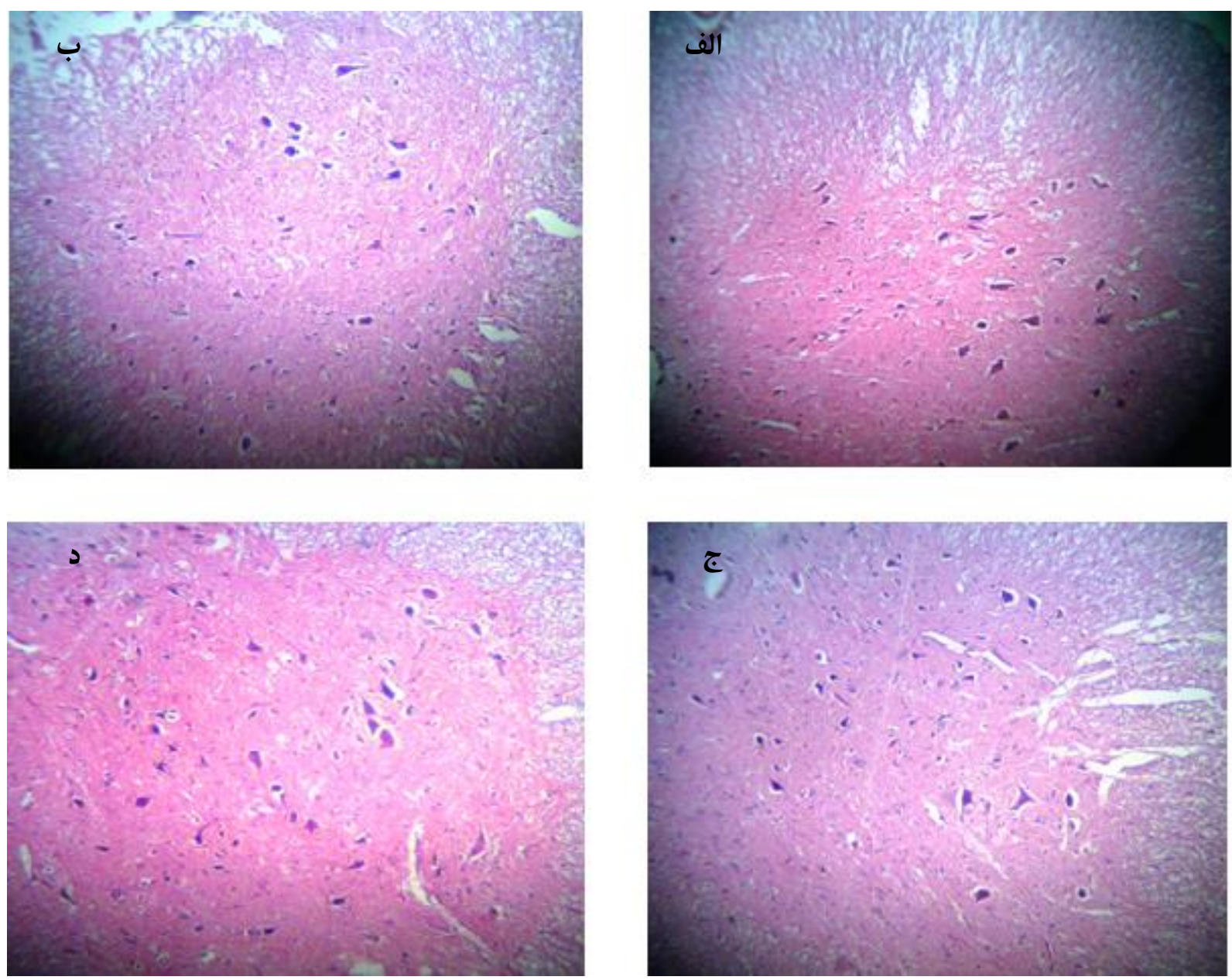

براى بررسى نتايج حاصل از تحقيق انجام شده، تصاوير تهيه شده

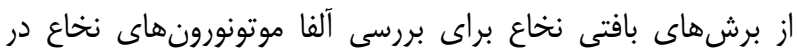
نيمه راست شاخ قدامى مورد بررسى قرار كرفت (تصوير ()).

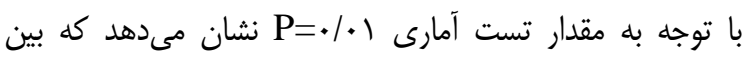

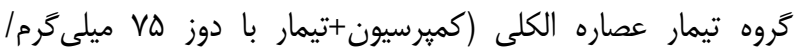

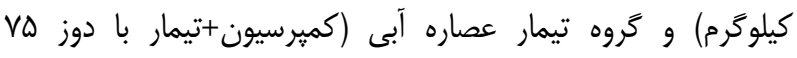

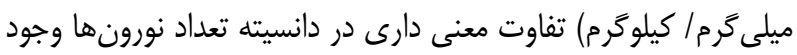

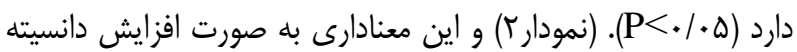
تعداد نورونها در گروه آبى ديده مىشود.

تصوير r- برش عرضى شاخ قدامى نخاع در تروههاى مختلف (درشت نمايى 100x). رنحَ آميزى هماتوكسيلين ائوزين

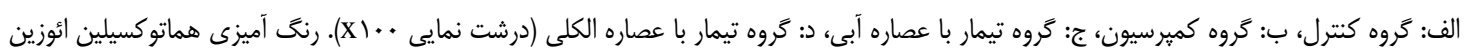


گروه هاى تيمار آبى و الكلى در ستونهاى آخر نشان داده شدهاند

تصوير (r).

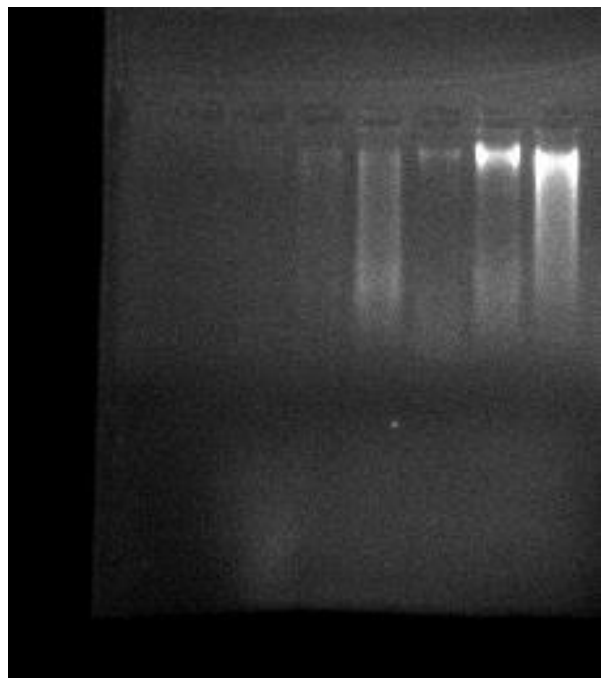

تصوير ץ- -نتايج حاصل از زل الكتروفورز

نتايج حاصل از بيان زن كاسياز س در تروههاى مختلف

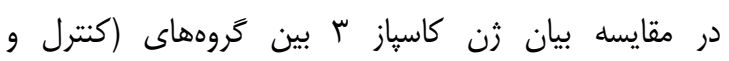
كميرسيون) و گروه كميرسيون با خروههاى عصاره الكلى و عصاره

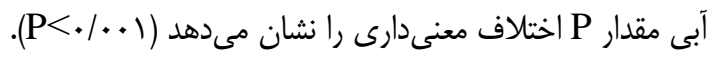

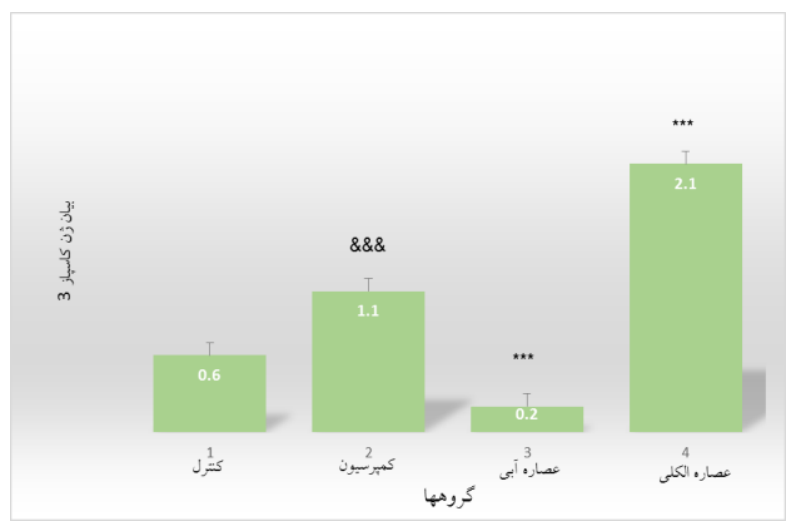

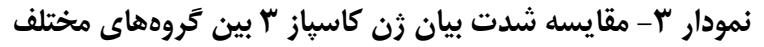
در هر كروه اعداد نشان دهنده ميانكين ثلنحراف معيار مىباشد.

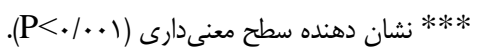
\&\& \& \& مقايسه كروه كترل با كمير سيون را نشان مىدهد. **** مقايسه كروه هاى تيمار با كمير سيون را نشان مىدهد.
در گروه كنترل جسم سلولى نورونهاى سالم مىباشد. هسته در مركز قرار گرفته و شكل نورونها بهحالت كروى است.

در كروه كميرسيون هسته به كنار رانده شده است و بلتدريج در حال

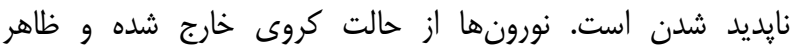
جندوجهى بلهود كرفته است.

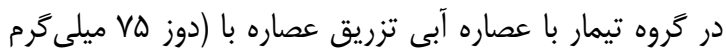
بر كيلوكرم) يس از كميرسيون عصب سياتيك موجب تغييرات

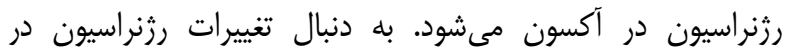

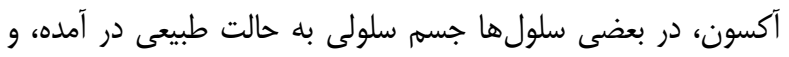
تورم سلولى كم مىشود. اين تغييرات در عصاره آبى مشهودتر است.

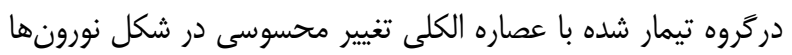
مشاهده نمى شود. ظاهراً اجزاى موثر گياه در اين عصاره نبوده است.

\section{نتايج حاصل از نانودراب}

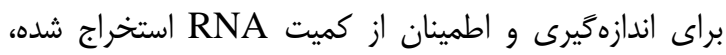
كميت توتال RNA به روش نانودراب مورد سنجش قرار كرفت و نتايج حاصل در جدول ه درج شده است. جدول ه- غلظت RNA استخراج شده

\begin{tabular}{|c|c|}
\hline $\begin{array}{c}\text { غلظت } \\
\text { RNA( } \mu g / \mu L)\end{array}$ & كروه \\
\hline$\cdot 1 \cdot 0$ & كنترل \\
\hline $.1 \cdot 1$ & كميرسيون \\
\hline$\cdot 11$ & كميرسيون+عصاره آبى با دوز VD ميلى كرم \\
\hline $.1 \cdot 4$ & كميرسيون+عصاره الكلى با دوز VD ميلى \\
\hline
\end{tabular}

\section{نتايج حاصل از Run كردن RNA روى زل الكتروفورز}

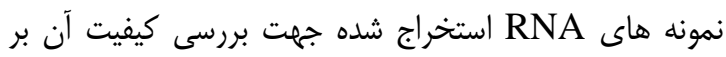

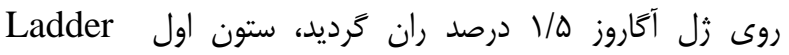
هاى موجود RNA ران (100bp) را به صوررت ץ باند مجزا نشان مىدهد. همانطور كه در مان نتايج

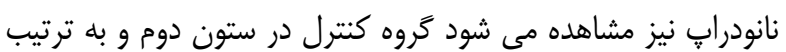


در شاخ قدامى نخاع شده و در نهايت دانسيته نورونى در كروه كميرسيون در مقايسه با كنترل كاهش معنا دارى دارد (نمودار ().

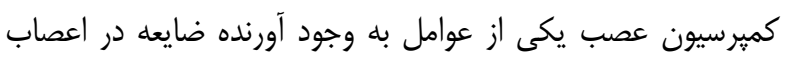

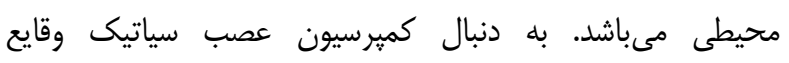
بيولوزيكى متعددى در سطح سلولى و مولكولى روى مى مدهد كه از

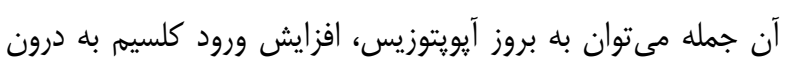

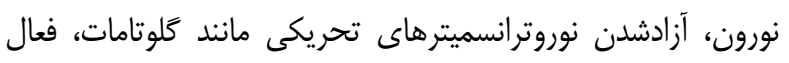

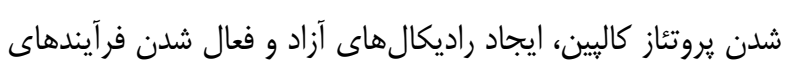

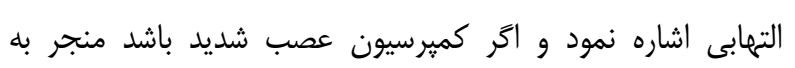

$$
\text { دزنراسيون مركزى در نخاع مى گردد (19). }
$$

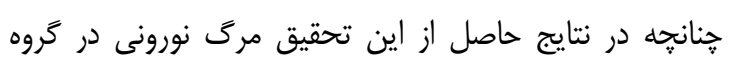

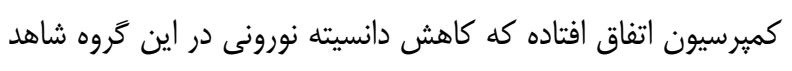

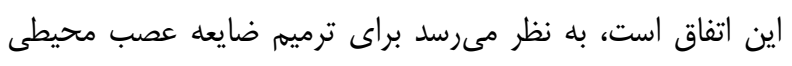

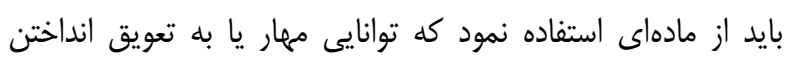

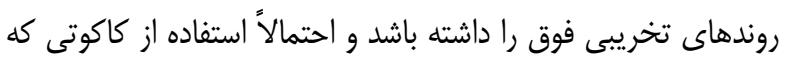
داراى طيف وسيعى از خواص فارماكولوزيكى و ويثگى هاى بارز

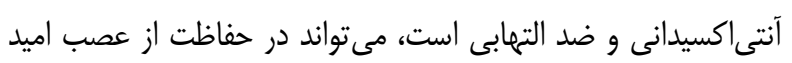

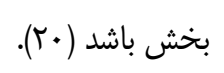

از جمله تركيبات طبيعى موجود در كياهان خانواده نعناعيان

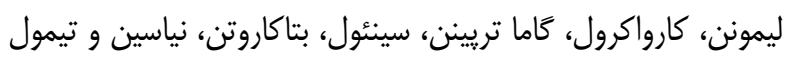
مى باشد. در مطالعهاى كه توسط كلشنى و همكارانبر روى كياهى از

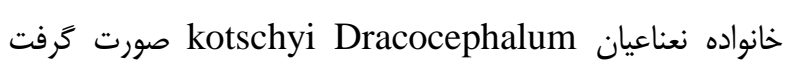
مشخص شد كه اين گياه به دليل وجود تركيباتى نظير ليمونن و آلفا تريينول داراى خاصيت ضد دردى مى باشد (آل).

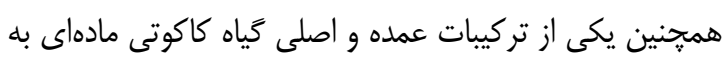

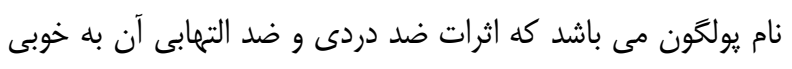

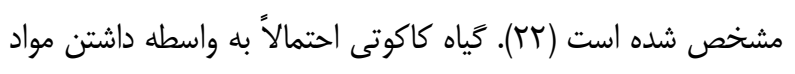

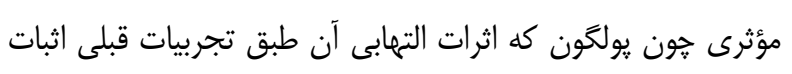

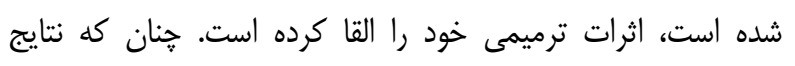

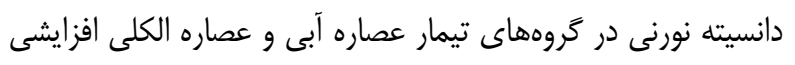

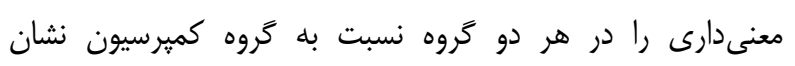

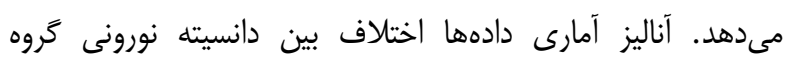

\section{نتايج حاصل از بيان زن كاسياز 9 در تَروههاى مختلف}

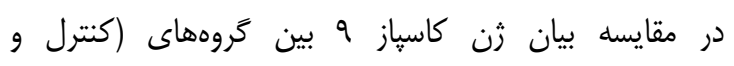
كميرسيون) و گروه كميرسيون با گروههاى عصاره الكلى و عصاره

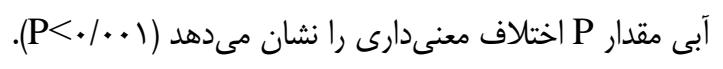

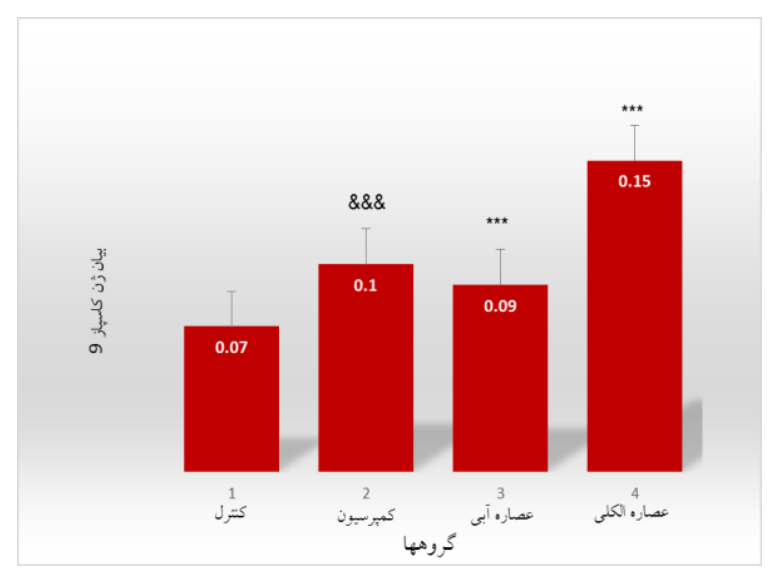

نمودار ؟ - مقايسه شدت بيان زن كاسباز 9 بين تروههاى مختلف در هر كروه اعداد نشان دهنده ميانكيني|نحراف معيار مى مباشد.

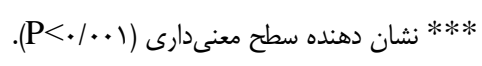
\&\& \& \& مقايسه كروه كتترل با كمبرسيون را نشان مىدهد. **** مقايسه كروههاى تيمار با كميرسيون را نشان مىدهد.

ضايعات سيسته عصبى گاهى غير قابل برثشت و جبران

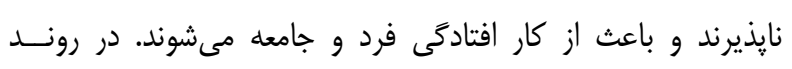

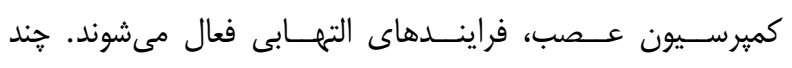

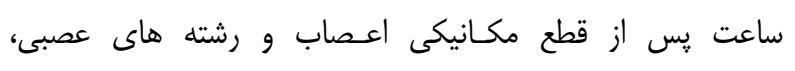

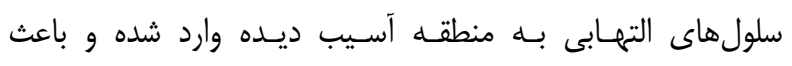

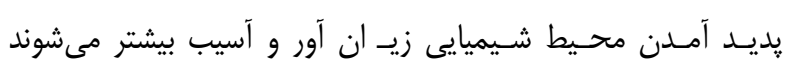

همان طور كه در قسمت نتايج مشاهده مى

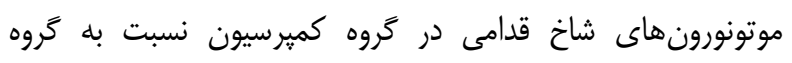

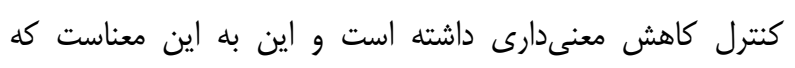
كميرسيون عصب سياتيك جانور سبب پِديد آمدن اثرات درنراسيون مركزى به صورت رتروگراد به سمت جسم سلولى نورونهاى حركتى 
فرايندهاى آيويتوز باشد.

نتايج يزوهش حاضر نشان مىدهد كه مقايسه بيان زن كاسياز

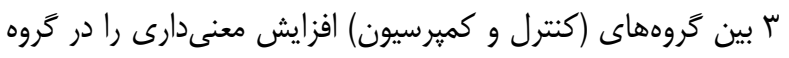

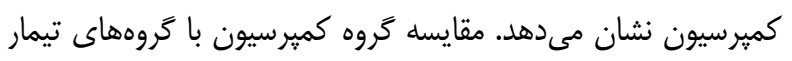

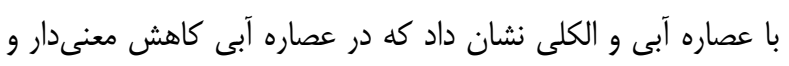
در عصاره الكلى افزايش معنى دارى براى بيان زن كاسپاز بّ مشاهده

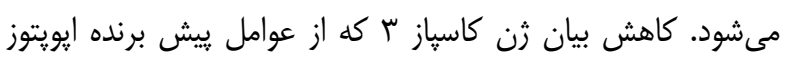

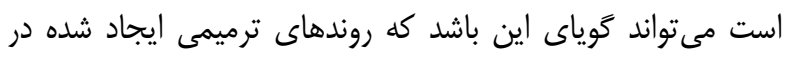

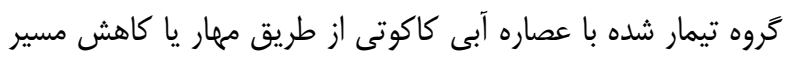

$$
\text { آيويتوز داخل سلولى بوده است (l). }
$$

در اين تحقيق در گروه تيمار با عصاره آبى كمترين ميزان بيان زن كاسياز ب مشاهده شد كه با نتايج تعداد نورونها كه بيشترين

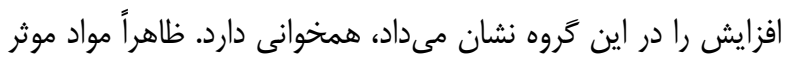

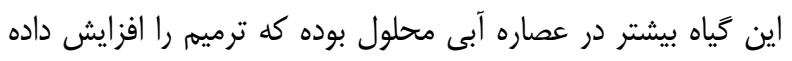

ميزان بيان ثن كاسباز 9 در گروه كميرسيون نسبت به كنترل افزايش قابل توجهى داشته كه نشان دهنده القاى آيويتوز در اين

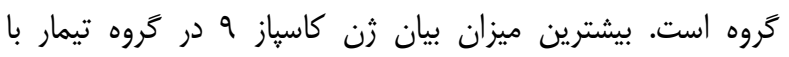
عصاره الكلى است كه نشان دهنده القاى آيويتوز است و با نتايج

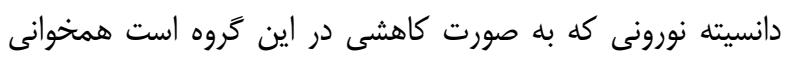

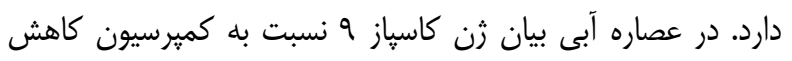

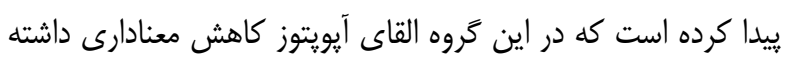

نتايج نشان مىدهد كه ظاهراً عصاره آبى اين كياه توانسته

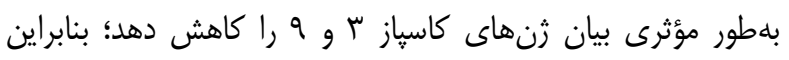

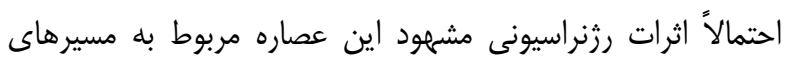

$$
\text { سيخنالينگ كاسِازى مىباشد. }
$$

با بررسى نتايج اين يزوهش مشخص ماسلد شد كه در لامهاى

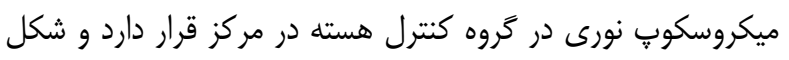
نورون كروى بوده است؛ ولى در گروه كميرسيون هسته در كنار و و كرون جروكيده مىباشد؛ در كروههاى تيمار نورونها مجدداً به سمت مركز سلول بركشته است كه در گروه تيمار با عصاره آبى هستهها واضحتر
تجربى با عصاره آبى با كمبرسيون را معنىدار توضيح مىدهد. در حالى كه اين افزايش در كروه تجربى الكلى معنى دار نيست. از آنجايى آنسي

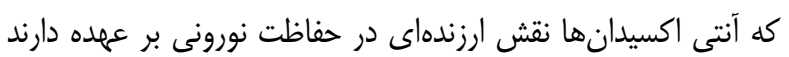

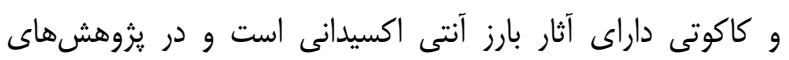

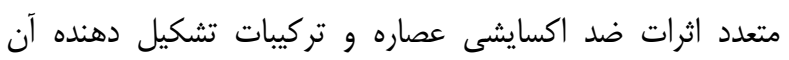
كزارش شده است؛ بنابراين احتمال دارد اثرات ترميمى عصارههاى

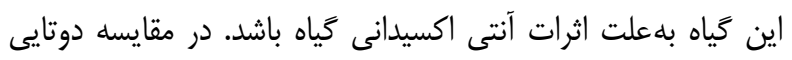

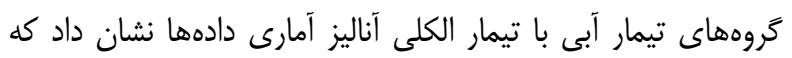

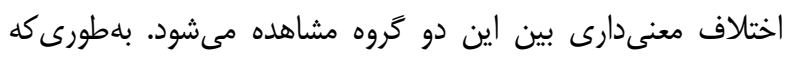

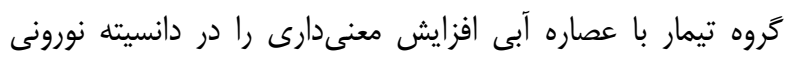

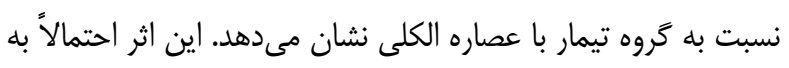

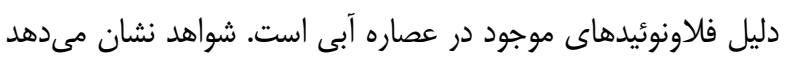

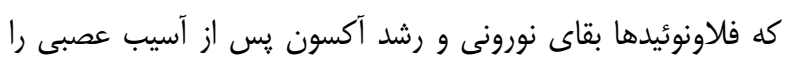

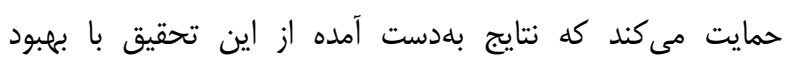

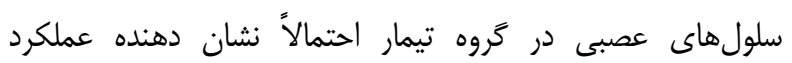

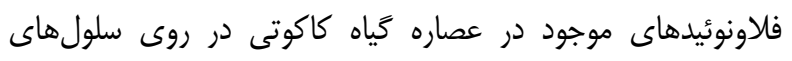

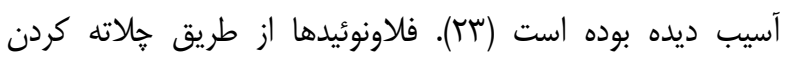

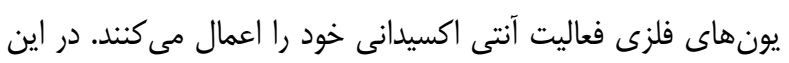

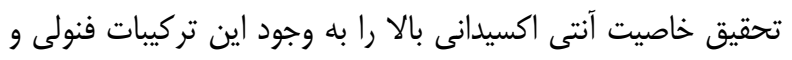

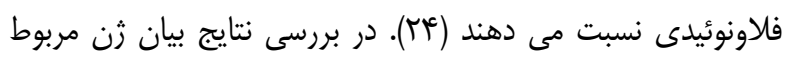

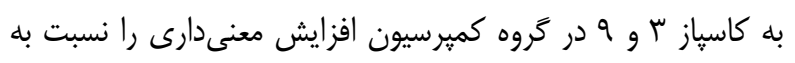

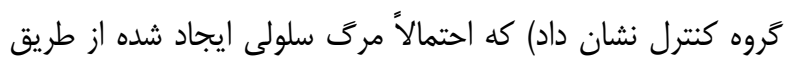
القاى كميرسيون بهعلت افزايش بيان ثنهاى كاسياز ّاّ و 9 مىتواند

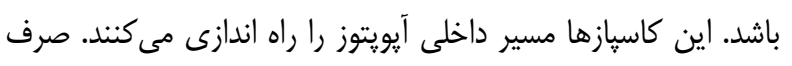

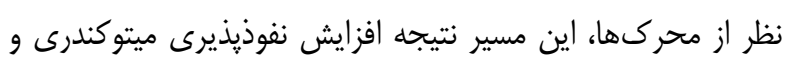

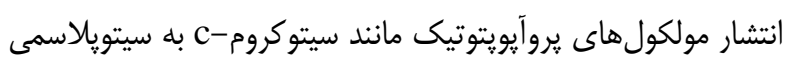
ايجاد مىشود. محركهاى داخلى مانند آسيبهاى غيرقابل جبران

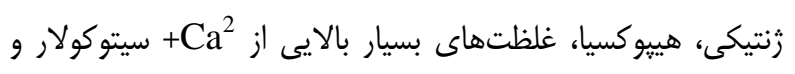
استرس اكسيداتيو شديد، برخى از عوامل ايجاد آيويتوز درون سلولى إنى

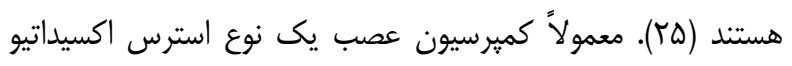

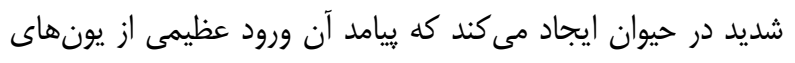
كلسيم به سلول مىباشد؛ بنابراين مىتواند عاملى براى ايجاد ونداد 


$$
\begin{aligned}
& \text { نرمال كزارش مىكند. احتمالاً فراكسيون عصاره آبى گياه كاكوتى } \\
& \text { داراى جز موثرى است كه باعث اين بهبودى مى مئل احتمد. }
\end{aligned}
$$

\section{تقدير و تشكّر}

اين تحقيق حاصل باياننامه با كد •هأبا است كه در كروه

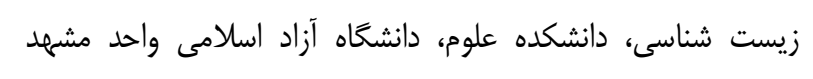

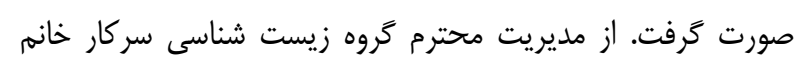

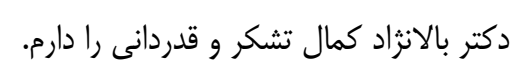

$$
\begin{aligned}
& \text { تضاد منافع } \\
& \text { نويسندكان مقاله اعلام مىدارند كه هيج گَونه تضاد منافعى در }
\end{aligned}
$$

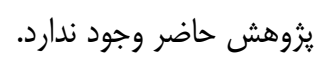

$$
\begin{aligned}
& \text { ديده مىشوند و تشابه بيشترى به گروه كنترل نشان مىدهد. } \\
& \text { نتيجه كيرى } \\
& \text { نتايج حاصل از اين تحقيق نشان داد كه كمبرسيون عصب } \\
& \text { سياتيك سبب ضايعات سيستم عصبى مركزى شده است؛ به كونهاى }
\end{aligned}
$$

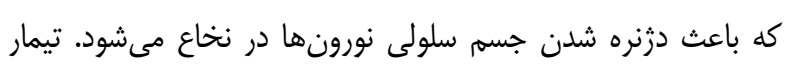

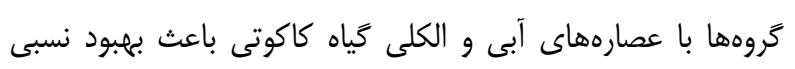

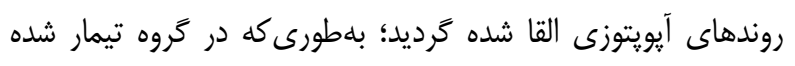

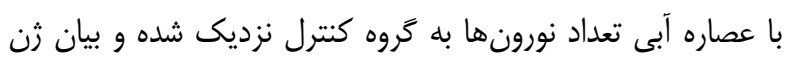

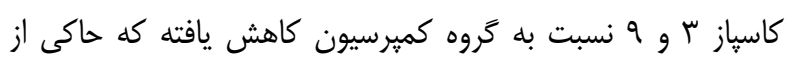

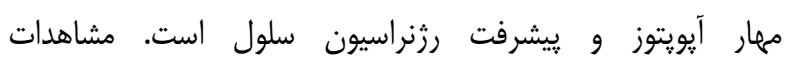

$$
\begin{aligned}
& \text { ميكروسكوٍ نورى وضعيت سلولها را در اين گروه مشابه سلول }
\end{aligned}
$$

1- Tehranipour M, Bahar ara J, Mostafaee M. The neuroprotective effect of CSF interaperitotoneal injection on alpha motor degeneration after sciatic nerve compression in rat. J Arak Uni Med Sci. 2009; 12(3): 101-8. [Persian]. Link

2- Tehranipour M, Javadmoosavi Z. The Neuroprotective Effect of Alcoholic Extract of Cannabis Sativa on Neuronal Density of Spinal Cord Alpha Motoneurons after Sciatic Nerve Injury in Rats. J Shahid Sadoughi Uni Med Sci. 2011; 19(3): 339-49. [Persian]. Link

3- Coleman MP, Conforti L, Buckmaster EA, Tarlton A, Ewing RM, Brown MC, et al. An 85- kb tandem triplication in the slow Wallerian degeneration (Wlds) mouse. Proc Natl Acad Sci USA. 1998; 95(17): 9985-90. DOI: 10.1073/pnas.95.17.9985

4- Lebel-Hardenack S, Grant SR. Genetics of sex determination in flowering plants. Trends Plant Sci.1997; 2(4): 130-6. DOI: $10.1016 /$ S1360-1385(97)01012-1

5- Zeinali H, Arzani A, Razmjoo R, Rezaee MB. Evaluation of Oil Compositions of Iranian Mints (Mentha ssp.). 2005; 17: 156-59. DOI: 10.1080/10412905.2005.9698863

6- Salehi P, Sonboli A, Eftekhar F, NejadEbrahimi S, Yousefzadi M. Essential oil composition, antibacterial and antioxidant activity of the oil and various extracts of Ziziphora clinopodioides subsp. rigida (BOISS.) RECH. f. from Iran. Biol Pharm Bull 2005; 28(10): 1892-6. DOI: 10.1248/bpb.28.1892.

7- Basak S, Hoffmann A. Crosstalk via the NF-kappaB signaling system. Cytokine Growth Factor Rev. 2008; 19(3-4): 187-197. DOI: 10.1016/j.cytogfr.2008.04.005

8- Aris A, Marrinhas E, Carvalho R, Dias C, Saavedra MJ. Phytochemical Composition and Antibacterial Activity of ahaydroalcoholic Extract of Pterospartum tridentatum and Mentha Pulegium against Staphylococcus aureus Isolates. Biomed Res int. 2016; 2016:5201879.1-12. DOI: 10.1155/2016/5201879

9- Fadaei F, Zahedi L, Farahani Z, Ghasemzade N. Review of two version of declaration of Helsinki (2013 and 2008): challenges and changes. J Med Ethics Hist Med. 2016; 9 (3); 75-92. Link

10- Cicchetti E, Chaintreau A. Comparison of extraction techniques and modeling of accelerated solvent extraction for the authentication of natural vanilla flavors. J Sep Sci. 2009; 32(11): 1957-64. DOI: 10.1002/jssc.200800650 
11- Tehranipour M, Attariyan F.The neuroprotective effect of stachys lavandulifolia Vahl leaves aqueous extract on the density of alpha neurons in anterior horn of spinal cord after sciatic nerve compression in rats. J shahrekord Univ Med Sci. 2015; 17(2): 119-126. [Persian]. Link

12- Alikhanzade M, Tehranipour M, Khayatzade J. The study of effect of aquatic extracts of Achillea biebersteinii leave on repair alpha motoneurons after sciatic nerve injury in rat. J Shahrekord Univ Med Sci. 2013; 15(4): 16-25. [Persian]. Link

13- Razavi M, Tehranipour M, Khayatzade J .Effects of aqueous extract saliva chloroleuca leaves on degeneration alpha motoneurons in spinal cord after sciatic nerve compression in rat. J Shahrekord Univ Med Sci. 2014; 16(2): 22-30. Link

14- Behnam-Rasouli M, Nikravesh M, Mahdavi-Shahri N, Tehranipour M. Post-Operative time effect after sciatic nerve crush on the number of alpha motonrurons using asterio gical counting metod (Dissector). Iran Biomed j. 2000; 4(1): 45-9. [Persian]. Link

15- Sterio DC. The unbiased estimation of number and sizes of arbitrary particles using the disector. J Microsc.1994; 134(Pt 2): 127-36. DOI: 10.1111/j.1365-2818.1984.tb02501.x

16- Atawodi S.E, Atawodi J.C, Dzikwi A. Polymerase chain reaction: Theory, practice and application: A review. 2011; Sahel Med. 2010; 13(2): 54-63. DOI: 10.4314/smj2.v13i2.64834

17- Jeon S, Kumar Jha M, Ock J, Suk K. Role of Lipocalin-2-Chemokine Axis in the Development of Neuropathic Pain following Peripheral Nerve Injury. J Biol Chem. 2013; 288(33): 24116-27. DOI: 10.1074/jbc.M113.454140

18- Rowinsky E, Donehower R. The clinical pharmacology and use of antimicrotubule agents in cancer chemotherapeutics. Pharmacol Ther. 1991; 52(1): 35-84. DOI: 10.1016/0163-7258(91)90086-2

19- Hanz Sh, Fainzilber M. Retrograde signaling in injured nerve - the axon reaction revisited. J Neurochem. 2006; 99(1): 13-9. DOI: $10.1111 /$ j.1471-4159.2006.04089.x

20- Mohamed A, Shoker A, Bendjelloul F, Mare A, Alzrigh M, Benghuzzi Het al. Improvement of experimental allergic encephalomyelitis (EAE) by thymoquinone: an oxidative stress inhibitor. Biomed Sci Instrum. 2003; 39: 440-5. Link

21- Golshani S, Karamkhani F, Monsef Esfehani HR, Abdollahi M. Antinociceptive effects of the essential oil of Dracocephalum kotschyi in the mouse writhing test. J Pharma Pharmaceut Sci 2004; 7(1): 76-9. Link

22- De Sousa DP, Junior EV, Oliveira FS, De Almeida RN, Nunes XP, Barbosa-Filho JM. Antinociceptive activity of structural analogues of rotundifolone: structure-activity relationship. Z Nature Forsch [C] 2007; 62 (1-2): 39-42. Link

23- Stankiewicz AR, Lachapelle G, Foo CP, Radicioni SM, Mosser DD. Hsp70 inhibits heat-induced apoptosis upstream of mitochondria by preventing Bax translocation. J Biol Chem. 2005; 280: 38729-38733. DOI: 10.1074/jbc.M509497200

24- Kang MH, Reynolds CP, Bcl-2 inhibitors: Targeting mitochondrial apoptotic pathways in cancer therapy. Clin Cancer Res. 2009, 15(4): 1126-1132. DOI: 10.1158/1078-0432.CCR-08-0144

25- Goldar S, Shekari Khaniani M, Mansoori Derakhshan S, Baradaran B. Molecular mechanisms of apoptosis and roles in cancer development and treatment. Asian Pac J Cancer Prev. 2015; 16(6): 2129-44. DOI: 10.7314/apjcp.2015.16.6.2129. 